\title{
Artists' Books Collection Development: Considerations for New Selectors and Collections
}

In the 2010 survey Taking Our Pulse: The OCLC Research Survey of Special Collections and Archives, artists' books were the specific genre most often identified as a new collecting area within library special collections departments. ${ }^{1}$ For librarians at institutions without an artists' books collection, beginning and sustaining the growth of a new collection can be an exciting and challenging opportunity to become acquainted with an additional area of specialized knowledge. Other librarians may be at institutions that possess a fledgling collection of artists' books but find that collecting priorities or guidelines need to be determined prior to more active collection development efforts. In the fall of 2016, with the goal of identifying current and established collection models, the author visited librarians working with collections of artists' books, distributed an online survey, and conducted a selective literature review. This article presents patterns identified in the survey results.

There have been many attempts in art and library literature to define just what an artist's book is. In her seminal work The Century of Artists' Books, Johanna Drucker considers the history and production of artists' books a "zone of activity" rather than attempting to narrowly define the art form. ${ }^{2}$ The Getty Art and Architecture Thesaurus distinguishes between several terms within the following entry:

Books, whether unique items or multiples, made or conceived by artists, including commercial publications (usually in limited editions), as well as unique items formed or arranged by the artist.... For artists' books that emphasize the physical book as a work of art rather than the content, use 'bookworks.' For works that look like or incorporate books but do not communicate in the ways characteristic of books, see "book objects."

1. Jackie M. Dooley and Katherine Luce, Taking Our Pulse: The OCLC Research Survey of Special Collections and Archives (Dublin, Ohio: OCLC Research, 2010), 27.

2. Johanna Drucker, The Century of Artists' Books (New York, N.Y.: Granary Books 2004), 1.

3. J. Paul Getty Trust and Getty Research Institute, Art \& Architecture Thesaurus Online, s.v. "artists' books (books)" (Los Angeles, Calif.: J. Paul Getty Trust, 2000), available online at www.getty.edu/research/tools/vocabulary/aat/ [accessed 9 December 2016].

๑ 2017 by D. Courtenay McLeland (CC BY-NC [https://creativecommons.org/licenses/by-nc/4.0/]). 
Within this article, the term artists' books will be used to encompass bookworks and book objects as well.

\section{Artists’ Books in Library Collection Development Literature}

Artists' books and their place in library collections have been discussed in the literature since the mid-1970s. Following an active period of growth in the production of artists' books in the sixties, librarians made efforts to become acquainted with and to collect these unique materials. In the 1977 publication Art Library Manual: A Guide to Resources and Practice, a chapter by Clive Phillpot addressed a range of issues beginning with defining terminology and the role of artists' books in library collections, followed by the more practical considerations of selection, classification, preservation, and shelving. Phillpot acknowledged that there may be a learning process for selectors stating "it should be said that it may take a while to get a feel for what artists using the book form are trying to convey." 4 A multiauthor collection of articles edited by Phillpot in the December 1982 issue of Art Documentation was devoted to collecting artists' books and addressed evaluation, acquisition, description, and other areas of concern to librarians. ${ }^{5}$ Within the "Acquisition of Artists' Books" section, Janet Dalberto provided an interesting analysis of the artists' book market in 1982. Dalberto also discussed the use of exhibition catalogs and the Franklin Furnace Archive Artists' Book Bibliography cards, published between 1977 and 1979, to inform collection development. ${ }^{6}$ In 1992, Simon Ford conducted a survey and shared the results in his article "Artists' Books in UK \& Eire Libraries.” Ford's survey received 51 responses that included academic, public, and museum libraries. Ford discussed the value that artists' books can offer to library collections along with the areas of selection, cataloging, storage, and exhibition. In looking at the formation of collecting priorities and the role of curriculum, Ford pointed out that "Academic libraries are guided, but not necessarily restricted, by what their parent institution teaches."' Similar questions of collection building, care, and display were addressed by authors Andrea Chemero, Caroline Seigel, and Terrie Wilson in the spring 2000 issue of Art Documentation. The article, "How Libraries Collect and Handle Artists' Books," shared brief personal interviews and the results of a 1999 survey submitted to the ARLIS-L listserv that received 27 responses. The subject of the digital artists' book was also briefly discussed, as found in formats such as CD-ROM and bookmarked URLs. ${ }^{8}$ In 2002, Terrie Wilson examined

4. Clive Phillpot, "Artists' Books and Book Art," Art Library Manual: A Guide to Resources and Practice (New York, N.Y.: Bowker, 1977), 358.

5. Clive Phillpot et al., "An ABC of Artists' Books Collections," Art Documentation: Bulletin of the Art Libraries Society of North America 1.6 (Dec. 1982): 169-81.

6. Ibid., 169.

7. Simon Ford, "Artists' Books in UK \& Eire Libraries," Art Libraries Journal 18.1 (1993): 16.

8. Andrea Chemero, Caroline Seigel, and Terrie Wilson, "How Libraries Collect and Handle Artists" Books," Art Documentation: Bulletin of the Art Libraries Society of North America 19.1 (Spring 2000): 22-25. 
the value of collection development policies and guidelines in her article "Collection Development Policies for Artists' Books." Wilson found that a separate artists' book policy was warranted in her institution and suggests that policies include sections detailing the history of the library's collection, purpose of the collection, selection guidelines, sources for acquisition, and more. ${ }^{9}$ The 2005 article "Artists' Books in Libraries: A Review of the Literature" by Louise Kulp also offered a thorough discussion of issues including collection development, acquisitions, cataloging, and programming. Kulp addressed that binding styles and craftsmanship may influence librarians' collecting decisions and points out that occasionally artists" books collection policies have a "deliberate inclusion or exclusion of certain subspecialty formats." ${ }^{10}$ Stephen J. Bury addressed the subject broadly in his 2007 article "1, 2, 3, 5: Building a Collection of Artists' Books" with attention to the potential for unusual materials and housing needs. ${ }^{11}$ In 2012 Annie Herlocker took an in-depth look at shelving and housing concerns in her article "Shelving Methods and Questions of Storage and Access in Artists' Book Collections." Herlocker conducted several interviews of special collections librarians and distributed a nine-question survey targeted to academic libraries that received a total of twenty responses. The article offers a set of boxing and shelving solutions employed by the surveyed libraries. ${ }^{12}$

The survey results that follow are intended to provide an update to the literature on current artists' books collecting and management practices in libraries by broadly examining the areas of selection, acquisition, preservation, description, and programming. An effort was made to keep the survey brief for participants. Were I to conduct a similar survey again, more questions identifying the characteristics of surveyed institutions would be included to improve the relevance of the results. Some areas of the survey, such as the questions related to preservation, drew richer free-text responses, and those are worth exploring more deeply.

\section{The Survey}

During November and December of 2016, the "Artists' Books Collection Development and Management Survey" was distributed to readers of three topical listservs: ARLIS/NA-L, Book Arts-L, and RBMS-L. The survey included 14 questions addressing the areas of collection development, description, preservation, and

9. Terrie L. Wilson, "Collection Development Policies for Artists' Books," Art Documentation: Bulletin of the Art Libraries Society of North America 21.1 (Spring 2002): 27.

10. Louise Kulp, "Artists' Books in Libraries: A Review of the Literature," Art Documentation: Bulletin of the Art Libraries Society of North America 24.1 (Spring 2005): 6.

11. Stephen Bury, "1, 2, 3, 5: Building a Collection of Artists' Books," Art Libraries Journal 32, no. 2: $5-9$.

12. Annie Herlocker, "Shelving Methods and Questions of Storage and Access in Artists' Book Collections," Art Documentation: Bulletin of the Art Libraries Society of North America 31, no. 1 (Spring 2012): 67-76. 
programming. Most questions included the option of an additional free-text entry, allowing respondents to share more in-depth answers. To comply with campus institutional research board recommendations, the anonymous survey link did not collect identifying information from participants, which would have allowed follow-up and further exploration. Regrettably, questions were omitted that would have clarified more about the institutions from which participants came, such as total library budget, size of institution, and geographic locations. Although 91 respondents clicked "I accept" and agreed to participate in the survey, the greatest number of responses gathered for any specific question was 76 . While the response rate seems small, the response $(n)$ is greater than those gathered in either the Ford or the Chemero-Seigel-Wilson studies. Percentages have been rounded to the nearest whole number throughout the text. See the appendix for survey questions, response totals, and corresponding percentages.

\section{Collection Size and Type}

The survey was not limited to a particular type of library. The first question asked about the primary administrative unit responsible for the artists' books collection. As anticipated, a majority of 71 percent of the 76 respondents to this question work with artists' books collections that are administered within a special collections unit. The second most common arrangement noted was within a branch or departmental library. Two respondents indicated in free-text entries that they are working in institutions with collections that are split between the main special collections unit and a branch art library.

Survey respondents came from institutions with various-sized collections of artists' books, with the majority representing collections of 1,000 or fewer items. Among the 76 respondents to question 2, 42 percent indicated that they work with holdings of fewer than 500 items. Another 30 percent work with collections between 500 and 1,000 items, 21 percent work with collections of more than 1,500 items, and nearly 7 percent work with collections that are between 1,000 and 1,500 items. With so many respondents working with collections of 1,000 or fewer items, smaller collections are typical of this type of material. The potential reasons for this are myriad, ranging from institutional support to space, but perhaps new collectors may find encouragement in the knowledge that modest collections are common.

\section{Collection Development Duties and Policies}

Of the 71 responses to the question "Does your organization have any collection development policies or guidelines specifically addressing artists' books?” there was a nearly even split, with 49 percent indicating that their institutions do. When asked about who forms collecting criteria for their institutions, 78 percent of the 69 respondents noted that there is a particular specialist or curator leading collec- 
CHART 1. Q2: How Many Items Are in the Artists' Book Collection?

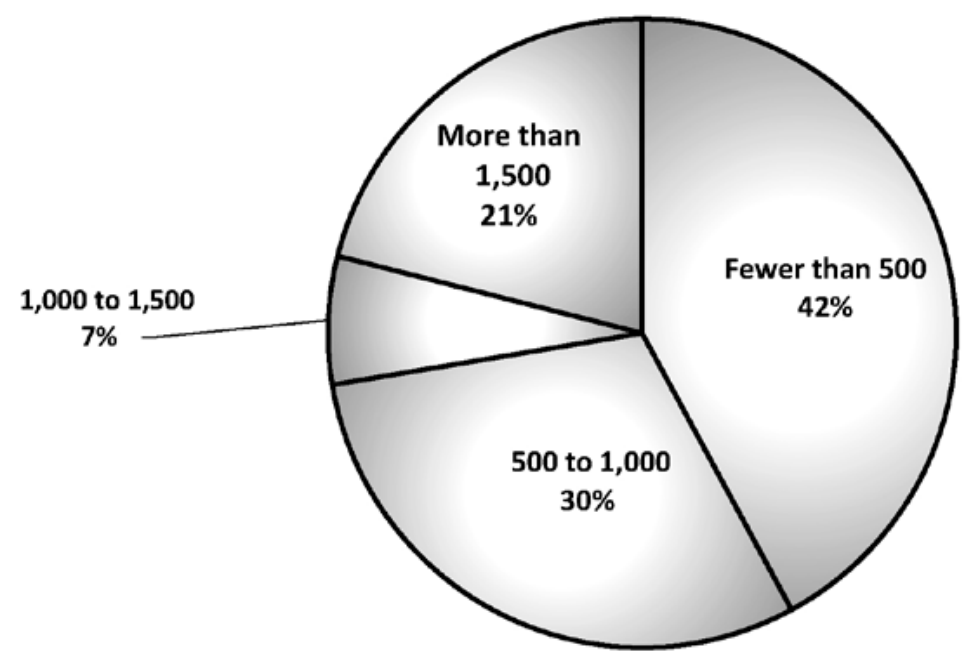

tion development efforts. Free-text responses also included examples of collecting duties shared among subject or liaison librarians, collection development librarians, and special collections librarians. Very few respondents indicated that they work through a committee for this type of collection development. Input from faculty outside the library also figured prominently, as selected by 43 percent of the respondents. One response indicated an effort to have regional libraries to meet with vendors collectively, ensuring that collections are well diversified.

Taking geographic and regional interests into account, selectors may want to determine whether there are other nearby institutions selecting similar material and how best to expand upon or complement those efforts. There may be regional presses or artists whose work should be considered for acquisition. While it may be possible with appropriate funding to acquire canonical artists' books, newer collectors and those with less funding could begin by selecting representative examples, followed by a focus on regional or local artists and presses.

To begin developing policies and priorities, libraries developing a new collection may want to review any collection development policies or selection guidelines that are already in place. Extant special collections or general collection development policies can provide a point of departure from which to further develop a policy specifically addressing artists' books. As selectors consider the purposes of the collection, the characteristics of potential audiences, and the needs they bring, collection priorities may begin to emerge. In an academic setting, maintaining familiarity with curricular needs through relationships with faculty is essential. While the obvious first groups to speak to may seem to be the faculty in litera- 
ture, art, and art history, other curricular areas beyond the humanities will be able to benefit from this material as well. The subject content explored within artists' books varies widely and can benefit students and faculty in many disciplines.

\section{Forming Collecting Criteria}

Beyond curricular support, there are many other ways to determine collecting priorities, ranging from regional interests, style or format, to particular creators. In the survey, participants were asked if specific subject areas, binding styles, or other criteria inform the institution's acquisition of artists' books. Respondents were able to select all applicable answers from a list of potential factors and enter free-text if needed. Responses indicated that selection decisions are influenced by a blend of attributes, such as subject or literary genres, techniques, processes, and binding styles. Librarians and patrons seeking artists' books may be equally concerned with the object or artistic qualities of works as they are with content. Nonetheless, 63 percent of the 73 respondents to question 4 chose subject areas or literary genres as a primary area of concern in selection decisions. Techniques, processes, and binding styles were included as criteria by 56 percent of the respondents. The pursuit of works by particular artists, authors, or presses was identified as a factor by 55 percent of the respondents. Collection priorities may also be influenced by the need to serve the region an institution is located in. A geographic or regional emphasis was identified as a selection factor by 52 percent of the respondents. In seeking to meet local needs, librarians may want to work collaboratively with other regional collectors to identify gaps or potential areas of focus in growing collections. In addition to building a stronger collection, this approach may help collectors make the best use of limited acquisitions funding.

\section{Methods of Acquisition}

Gifts are one way in which artists' books collections may begin or expand and are often the impetus for a new collecting direction in special collections units. ${ }^{13}$ Gifts were selected by 28 percent of respondents as a means through which their collections have grown. Beyond gifts, modes of acquiring artists' books include book fairs, booksellers and galleries specializing in artists' books, as well as pur-

CHART 2. Q4: Are there Specific Subject Areas, Binding Styles, or Other Criteria that Inform the Institution's Acquisitions in this Area? (Select all that apply.)

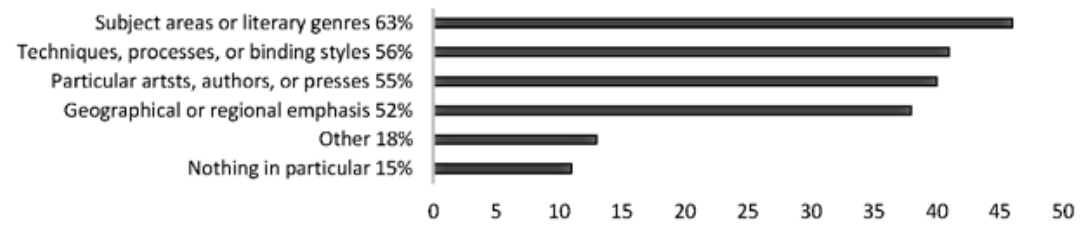

13. Dooley and Luce, Taking Our Pulse, 27. 
chasing directly from artists. Participants were asked whether they emphasized particular approaches to building collections, with the option to select more than one method. Over half of the respondents, 54 percent, indicated that they employ a combination of approaches with no emphasis on a particular method to grow their collections. Nearly half of the respondents, 49 percent, indicated that they purchase items through a gallery or bookseller. Some booksellers assist with collection development efforts by offering consultation services, arranging standing orders, and providing annotated lists of suggested material to institutional collectors. Direct purchases from artists, not during a book fair, was chosen by 33 respondents, or 46 percent of the respondents, though 31 percent indicated that they do purchase material during book fairs. Although purchases made directly from artists may be a bit more time consuming to negotiate, any additional information about the piece and the artist's biography that comes directly from the source will be of great value to those tasked with describing and providing metadata for the work.

\section{Preservation and Housings}

As a testament to the diversity of the form, artists' books are embodied in a vast range of physical formats. Collections may include works that are more sculptural than book-like, multichamber boxes, scrolls, concertina, inexpensive photocopied works stapled together, complex three-dimensional examples of paper engineering, numerous binding styles, and boxes or portfolios of unbound pages. Materials used in artists' books are also often unusual, delicate, and potentially unstable. A few examples out of seemingly endless possibilities are fur, laser-cut paper and wood, handmade paper with inclusions, plant matter, mica and other minerals and stones, loosely woven fabrics, embroidered fabric, and more. This broad variety of material, size, shape, and complexity brings preservation challenges ranging from unusual materials to unique shapes that dictate housing and shelving decisions. In addition to the possible deterioration of the work itself, one must consider any potential impact on items shelved next to an oddly sized artists' book or one made with unstable materials. Collectors should be prepared for an increase in the need for either commercial or custom-built protective enclosures.

Housings and enclosures protect fragile items and mitigate potential risks to nearby materials while offering a method of standardizing storage spaces. While 62 percent of respondents indicated that the materials did not require special housing or preservation treatment beyond what is already customary for special collections materials in their institutions, many free-text entries indicated that protective enclosures are important and routinely provided for artists' books. Types of protective enclosures mentioned in the responses included clamshell boxes, acid-free folders, Mylar and glassine envelopes, tissue wrappings within boxes, and phased boxes. 


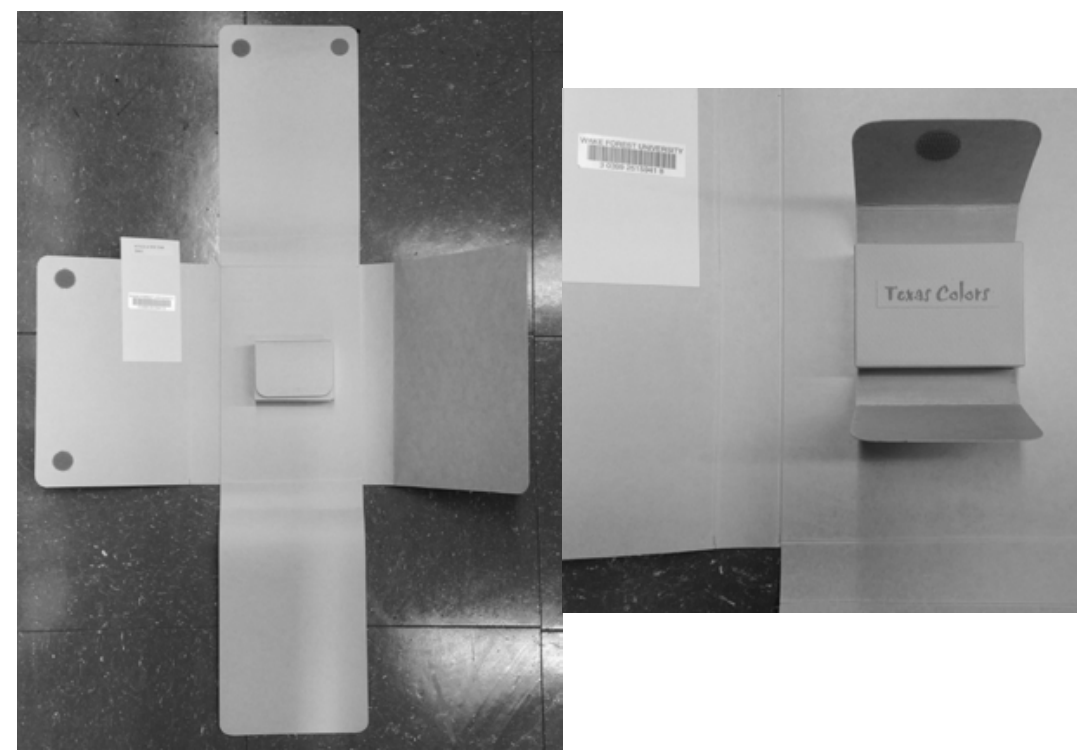

ILLUSTRATION 1-2. Custom enclosure created by Craig Fansler for Jill Timm, Texas Colors. (Images courtesy of Craig Fansler, Preservation Librarian, Special Collections \& Archives, Z. Smith Reynolds Library, Wake Forest University.)

In some cases, there is a need for additions not typical of regular housings, such as cutouts or support for three-dimensional elements in the work. The boxing of smaller or fragile items so they may sit on shelving next to other materials was mentioned within several responses. Most artists' books collections in the respondents' institutions are shelved in a limited-access area. Not addressed in the survey, but certainly worthy of further exploration, are the digital preservation challenges that may come with e-artists' books that are interactive or are in formats requiring specialized software.

\section{Access and Description}

With regard to extending control and encouraging use through bibliographic access to artists' books, respondents considered providing catalog records with thorough physical descriptions and additional terms to be very important, as indicated in a number of free-text responses. When asked how these records are made accessible, 84 percent of 70 respondents indicated that the works are added to a local library catalog or integrated library system, and more than 81 percent add holdings to OCLC as well. Other free-text responses emphasized the provision of visual access to the works such as creating an ArtStor Shared Shelf collection or adding the items to an institutional repository or digital asset management system.

Enhancements made to these records include series entries, extensive use of detailed notes fields, and additional terms added to MARC 655 fields to capture the genre, 
form, or physical characteristics. Respondents use applicable terms beyond the Library of Congress Subject Headings from a variety of sources including the Getty's Art and Architecture Thesaurus, the Thesaurus for Graphic Materials, the Ligatus Language of Bindings Thesaurus, a glossary of bookbinding terms, and Type Evidence, an ACRL Rare Books and Manuscripts Section controlled vocabulary. Respondents indicated that artists' and booksellers' websites are consulted for biographical information about artists and as a source for detailed information about binding styles, printing techniques, and materials. Information from the book's colophon is recorded in a notes field. Some respondents use 856 fields to link to images of the works. When asked about whether images of the works are created, 55 percent responded that none are made. Of those that do create images, 40 percent indicated that images are used for webpages or in digital exhibits, and 4 percent use images only for internal documentation or in basic catalog records. Collectors should address the subject of permissions for digital images upon acquisition whenever possible. ${ }^{14}$

\section{Programming and Exhibits}

Several questions at the end of the survey addressed programming and exhibits further. Of the 70 respondents to question 12, 67 percent indicated there is programming related to the artists' books collection. This is most often in the form of an exhibit, as chosen by 89 percent of those offering programming. Of the 47 respondents offering programming, 66 percent are hosting artists' talks, 49 percent offer hands-on workshops, and 32 percent offer digital exhibits. Class visits, either from within the institution or from students at other nearby institutions, also figured prominently in the free-text responses, and the majority work with faculty to encourage course-related use of the collection. In addition to single-session class visits, responses indicated more in-depth examples of instruction integrating artists' books collections. Other types of exposure for collections mentioned within responses were general tours of special collections to highlight the variety of materials available, fundraising events, publications clinics, binding workshops, buying fairs, and artists' residencies. It is clear from the results that programming and exhibits are considered to be an important part of the administration of artists' books collections.

\section{Conclusion}

During the last fifty years, artists' books have become a well-established and worthwhile area of collection development within libraries. Library literature has certainly grown to reflect that. Artists' books collections can offer patrons an engaging experience with books as objects, at a time when focused hands-on use of library materials is becoming rarer. The survey indicates that smaller collections

14. Alexandra Purcell, "Artists' Books, Digital Exhibitions, and the Copyright Issues that Surround Them," Art Documentation: Bulletin of the Art Libraries Society of North America 34, no. 2 (Sept. 2015): $321-29$. 
are relatively common and new collectors may find in this an opportunity to build a well-focused collection that meets the needs and interests of their constituents. There may be opportunities to collaborate with local and regional institutions to make the best selection decisions and use of limited collecting resources. With a set of priorities and budgetary parameters in mind, newer librarian collectors can become better acquainted with the field by attending book fairs and forming relationships with book artists, galleries, and booksellers. Taking advantage of any online catalogs and consulting services offered by booksellers, one may begin forming a sense of what is within the budget and how an item fits within the identified collecting goals. It should be noted that many artists' books by rising book artists are very affordable, so one should not fear that all acquisitions will take up large portions of the budget.

Responses in this survey suggest that the librarians managing these collections recognize preservation concerns in general, particularly housing and shelving arrangements, as important ongoing concerns. Thorough bibliographic description was also a prominent theme in the free-text responses. Sharing the collection through exhibits and other forms of programming is often among the activities of those charged with managing artists' books collections. With an emphasis on programming, exhibits, and the inviting hands-on nature and visual richness of these materials, librarians will want to prepare for the additional security risks and preservation needs that come with increased handling. Although artists' books bring unique challenges, librarians just beginning to work with such a collection may find Clive Phillpot's wisdom to be true of their experiences, that "while artists' books might seem to generate a whole new cluster of problems, these problems taken singly are in fact quite familiar to the experienced librarian." ${ }^{15}$

15. Phillpot et al., "An ABC of Artists' Books Collections," 169.

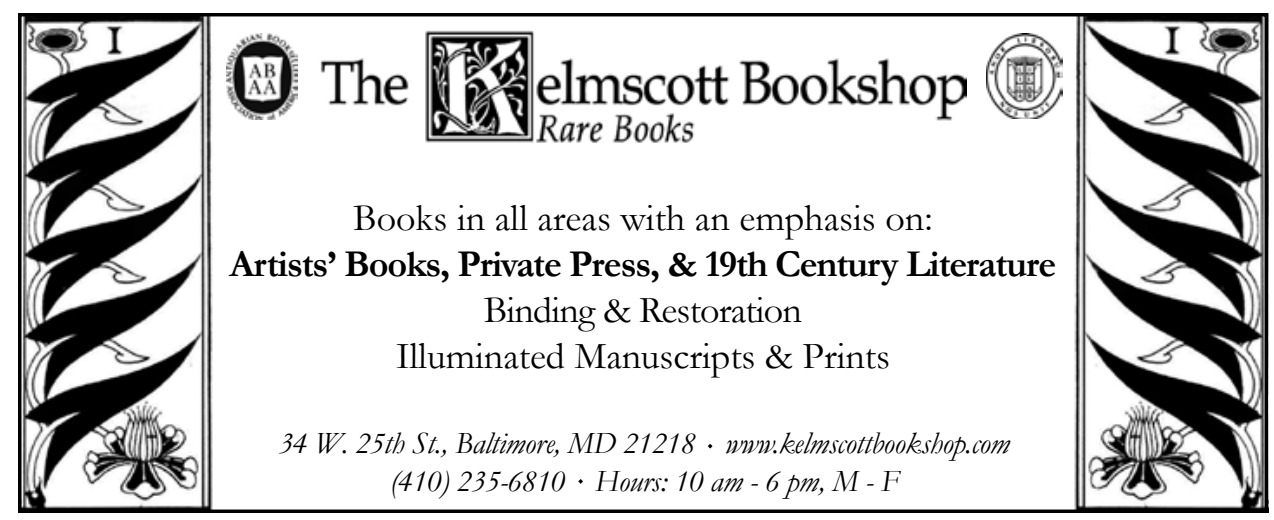




\section{Appendix. The Artists' Books Collection Development and Management Survey}

\begin{tabular}{|c|c|c|c|}
\hline $\begin{array}{l}\text { Survey Questions and } \\
\text { Responses Excluding Free- } \\
\text { text Entries }\end{array}$ & Answer Choices & Total & Percent \\
\hline \multirow{3}{*}{$\begin{array}{l}\text { Informed consent-By } \\
\text { clicking the "I accept" } \\
\text { button, you are indicating } \\
\text { that you agree to participate } \\
\text { in the study. }\end{array}$} & Yes & 91 & $97.85 \%$ \\
\hline & No & 2 & $2.15 \%$ \\
\hline & Total responses & 93 & \\
\hline \multirow{5}{*}{$\begin{array}{l}\text { Q1. Administratively, where } \\
\text { in your organization does } \\
\text { the responsibility for the } \\
\text { artists' book collection fit in? }\end{array}$} & $\begin{array}{l}\text { Within a special collections } \\
\text { unit }\end{array}$ & 54 & $71.05 \%$ \\
\hline & $\begin{array}{l}\text { Within a branch or } \\
\text { departmental library }\end{array}$ & 14 & $18.42 \%$ \\
\hline & $\begin{array}{l}\text { Within a museum } \\
\text { curatorial unit }\end{array}$ & 0 & \\
\hline & Other, please explain & 8 & $10.53 \%$ \\
\hline & Total responses to Q1 & 76 & \\
\hline \multirow{5}{*}{$\begin{array}{l}\text { Q2. How many items are in } \\
\text { the artists' book collection? }\end{array}$} & Fewer than 500 & 32 & $42.11 \%$ \\
\hline & $500-1,000$ & 23 & $30.26 \%$ \\
\hline & $1,000-1,500$ & 5 & $6.58 \%$ \\
\hline & More than 1,500 & 16 & $21.05 \%$ \\
\hline & Total responses to Q2 & 76 & \\
\hline \multirow{3}{*}{$\begin{array}{l}\text { Q3. Does your organization } \\
\text { have any collection } \\
\text { development policies or } \\
\text { guidelines specifically } \\
\text { addressing artists' books? }\end{array}$} & Yes & 35 & $49.30 \%$ \\
\hline & No & 36 & $50.70 \%$ \\
\hline & Total responses to Q3 & 71 & \\
\hline \multirow{7}{*}{$\begin{array}{l}\text { Q4. Are there specific } \\
\text { subject areas, binding styles, } \\
\text { or other criteria that inform } \\
\text { the institution's acquisitions } \\
\text { in this area? Select all that } \\
\text { apply. }\end{array}$} & $\begin{array}{l}\text { Subject areas or literary } \\
\text { genres }\end{array}$ & 46 & $63.01 \%$ \\
\hline & $\begin{array}{l}\text { Techniques, processes, or } \\
\text { binding styles }\end{array}$ & 41 & $56.16 \%$ \\
\hline & $\begin{array}{l}\text { Particular artists, authors, } \\
\text { or presses }\end{array}$ & 40 & $54.79 \%$ \\
\hline & $\begin{array}{l}\text { A geographic or regional } \\
\text { emphasis }\end{array}$ & 38 & $52.05 \%$ \\
\hline & No, nothing in particular & 11 & $15.07 \%$ \\
\hline & Other, please explain & 13 & $17.81 \%$ \\
\hline & Total responses to Q4 & 73 & \\
\hline
\end{tabular}




\begin{tabular}{|c|c|c|c|}
\hline $\begin{array}{l}\text { Survey Questions and } \\
\text { Responses Excluding Free- } \\
\text { text Entries }\end{array}$ & Answer Choices & Total & Percent \\
\hline \multirow{5}{*}{$\begin{array}{l}\text { Q5. For the collecting } \\
\text { criteria, were these areas } \\
\text { of focus formed with the } \\
\text { input of a committee, } \\
\text { subject specialists, curators, } \\
\text { faculty members, or other } \\
\text { constituents? Select all that } \\
\text { apply. }\end{array}$} & There is a committee & 5 & $7.25 \%$ \\
\hline & $\begin{array}{l}\text { There is a specialist or } \\
\text { curator }\end{array}$ & 54 & $78.26 \%$ \\
\hline & $\begin{array}{l}\text { There is input from faculty } \\
\text { outside of the library }\end{array}$ & 30 & $43.48 \%$ \\
\hline & $\begin{array}{l}\text { Other, please explain } \\
\text { below }\end{array}$ & 15 & $21.74 \%$ \\
\hline & Total responses to Q5 & 69 & \\
\hline \multirow{7}{*}{$\begin{array}{l}\text { Q6. Are there particular } \\
\text { methods used most often to } \\
\text { build the collection? Select } \\
\text { all that apply. }\end{array}$} & Gifts & 20 & $27.78 \%$ \\
\hline & $\begin{array}{l}\text { Purchased during a book } \\
\text { fair }\end{array}$ & 22 & $30.56 \%$ \\
\hline & $\begin{array}{l}\text { Purchased directly from } \\
\text { artists, not during a book } \\
\text { fair }\end{array}$ & 33 & $45.83 \%$ \\
\hline & $\begin{array}{l}\text { Purchased through a } \\
\text { gallery or bookseller, not } \\
\text { during a book fair }\end{array}$ & 35 & $48.61 \%$ \\
\hline & $\begin{array}{l}\text { A combination of } \\
\text { approaches, with no } \\
\text { emphasis on a particular } \\
\text { method }\end{array}$ & 39 & $54.17 \%$ \\
\hline & $\begin{array}{l}\text { Other, please explain } \\
\text { below }\end{array}$ & 4 & $5.56 \%$ \\
\hline & Total responses to Q6 & 72 & \\
\hline \multirow{3}{*}{$\begin{array}{l}\text { Q7. Are there any special } \\
\text { housing or preservation } \\
\text { concerns that have had to be } \\
\text { addressed? }\end{array}$} & $\begin{array}{l}\text { None beyond the usual } \\
\text { treatment of Special } \\
\text { Collections materials }\end{array}$ & 44 & $61.97 \%$ \\
\hline & Yes. Please explain: & 27 & $38.03 \%$ \\
\hline & Total responses to Q7 & 71 & \\
\hline \multirow{3}{*}{$\begin{array}{l}\text { Q8. Are there any } \\
\text { consistently applied } \\
\text { preservation, shelving, or } \\
\text { housing practices that apply } \\
\text { to most, if not all, items in } \\
\text { the collection? }\end{array}$} & No & 37 & $52.11 \%$ \\
\hline & Yes. Please explain: & 34 & $47.89 \%$ \\
\hline & Total responses to Q8 & 71 & \\
\hline
\end{tabular}




\begin{tabular}{|c|c|c|c|}
\hline $\begin{array}{l}\text { Survey Questions and } \\
\text { Responses Excluding Free- } \\
\text { text Entries }\end{array}$ & Answer Choices & Total & Percent \\
\hline \multirow{5}{*}{$\begin{array}{l}\text { Q9. In what ways are } \\
\text { records for these materials } \\
\text { made accessible? Are they } \\
\text { added to OCLC, an ILS, a } \\
\text { digital asset management } \\
\text { system, or stored in another } \\
\text { type of local database? } \\
\text { Select all that apply. }\end{array}$} & OCLC & 57 & $81.43 \%$ \\
\hline & $\begin{array}{l}\text { A local library catalog or } \\
\text { ILS }\end{array}$ & 59 & $84.29 \%$ \\
\hline & $\begin{array}{l}\text { In a digital asset } \\
\text { management system (such } \\
\text { as ContentDM) }\end{array}$ & 8 & $11.43 \%$ \\
\hline & Other; please explain: & 8 & $11.43 \%$ \\
\hline & Total responses to Q9 & 70 & \\
\hline \multirow{3}{*}{$\begin{array}{l}\text { Q10. Beyond traditional } \\
\text { description for books, are } \\
\text { there fields, values, or inputs } \\
\text { that are added for a more } \\
\text { thorough description? }\end{array}$} & If so, please explain: & 36 & $54.92 \%$ \\
\hline & No & 32 & $47.06 \%$ \\
\hline & Total responses to Q10 & 68 & \\
\hline \multirow{4}{*}{$\begin{array}{l}\text { Q11. Are images of the } \\
\text { works created? If so, are } \\
\text { they used to create an online } \\
\text { presence for the materials, in } \\
\text { digital exhibits, or simply for } \\
\text { record keeping purposes? }\end{array}$} & $\begin{array}{l}\text { Images are used in digital } \\
\text { exhibits or on a public } \\
\text { webpage }\end{array}$ & 28 & $40.58 \%$ \\
\hline & $\begin{array}{l}\text { Images are only used for } \\
\text { internal documentation or } \\
\text { basic catalog records }\end{array}$ & 3 & $4.35 \%$ \\
\hline & No images are made & 38 & $55.07 \%$ \\
\hline & Total responses to Q11 & 69 & \\
\hline \multirow{3}{*}{$\begin{array}{l}\text { Q12. Does your } \\
\text { organization offer any } \\
\text { programming specifically } \\
\text { related to the collection? }\end{array}$} & Yes & 47 & $67.14 \%$ \\
\hline & No & 23 & $32.86 \%$ \\
\hline & Total responses to Q12 & 70 & \\
\hline \multirow{7}{*}{$\begin{array}{l}\text { If yes selected in Q12 } \\
\rightarrow \text { Q13. What types of } \\
\text { programming have been } \\
\text { offered? Check all that apply. }\end{array}$} & Artist talks & 31 & $65.96 \%$ \\
\hline & Exhibits & 42 & $89.36 \%$ \\
\hline & Digital exhibits & 15 & $31.91 \%$ \\
\hline & Festivals & 0 & \\
\hline & Hands-on workshops & 23 & $48.94 \%$ \\
\hline & Other; please explain: & 14 & $29.79 \%$ \\
\hline & Total responses to Q13 & 47 & \\
\hline \multirow{2}{*}{$\begin{array}{l}\text { Q14. Has the library worked } \\
\text { with the faculty to integrate } \\
\text { artists' books into course } \\
\text { content or otherwise } \\
\text { encourage course-related } \\
\text { use of the collection? }\end{array}$} & If yes, please explain: & 59 & $84.29 \%$ \\
\hline & No & 11 & $15.71 \%$ \\
\hline
\end{tabular}

